\title{
PENENTUAN DEBIT RENCANA SITU DENGAN METODA NRECA DAN NAKAYASU (Lokasi Universitas Indonesia, Depok)
}

\author{
Determination Of Discharge Plan Resevoir With Nakayasu And NRECA Methods \\ (Location University Of Indonesia, Depok) \\ Oleh: \\ Teddy W Sudinda \\ Pusat Teknologi Lingkungan, Kedeputian TPSA, BPPT.
}

\begin{abstract}
Abstrak
Situ merupakan salah satu bangunan yang berfungsi untuk menyimpan air, dapat diartikan sebagai reservoir air di permukaan tanah yang berasal dari air tanah atau air permukaan. Dari sudut hidrologi, situ memiliki berbagai fungsi seperti konservasi sumber daya air, mengurangi bahaya banjir dan kekeringan. Dalam tulisan ini dianalisis rata-rata debit bulanan dan debit banjir rencana situ baru di wilayah Universitas Indonesia. Perhitungan rata-rata debit bulanan pada situ baru dengan menggunakan metode perhitungan rata-rata bulanan NRECA dan penguapan yang terjadi pada wilayah studi. Perhitungan debit banjir dengan menggunakan metode hidrograf sintetik Nakayasu dengan memperhitungkan curah hujan harian maksimum dan distribusi curah hujan.
\end{abstract}

Kata kunci : Debit Banjir, Metoda Nreca, Metoda Hidrograf Nakayasu.

\begin{abstract}
Reservoir is one building that serves to store water, can be interpreted as a water reservoir in the surface soil from ground water or surface water. From the point of hydrology, it has various functions such as conservation of water resources, reduce the danger of flooding and drought. In this paper analyzed the average monthly discharge and flood discharge plans new reservoir in the Indonesia University area. Calculation of average monthly discharge in reservoir using the new calculation method the average monthly NRECA and evaporation that occurs in the study area. The calculation of flood discharge using hydrograph synthetic NAKAYASU taking into account the maximum daily rainfall and rainfall distribution.
\end{abstract}

Keywords: Flood Discharge, NRECA Method, NAKAYASU Hydrograph Method.

\section{PENDAHULUAN}

Air adalah salah satu bagian terpenting dalam kehidupan manusia, hewan, tumbuhan serta mahluk hidup lainnya yang ada di muka bumi ini. Oleh karena itu kita harus berusaha untuk melestarikan sumber daya air yang ada di lingkungan sekitar. Perkembangan, pertumbuhan dan kemunduran suatu tingkat kehidupan dan kebudayaan manusia pada suatu bangsa, secara langsung akan dipengaruhi oleh mampu tidaknya suatu bangsa tersebut menjaga kelestarian sumber daya airnya dengan baik dan mengembangkannya secara bijaksana. Air dapat dijumpai dimana-mana, namun secara kuantitas sering kali sangat terbatas. Begitu pula dengan ketersediannya berada pada waktu dan letak geografis yang tidak sesuai, dengan kebutuhan dan juga kualitasnya sering juga kurang memadai. Oleh karena itu, tanpa adanya usaha-usaha pengelolaan dari manusia, sedikit banyak, tidaklah mungkin dapat memanfaatkan air secara optimal guna kemakmuran serta kesejahteraannya dengan jumlah, waktu dan lokasi yang dikehendaki. Suatu hal yang sangat menguntungkan adalah karena air merupakan kekayaan alam yang tidak bisa hilang. Yang selalu akan datang kembali pada suatu waktu, menurut siklus hidrologi. Apabila air yang akan datang dibiarkan mengalir ke laut dan tidak dimanfaatkan atau disimpan untuk digunakan untuk kepentingan bersama, berarti air akan terlewat begitu saja tanpa dapat dirasakan manfaatnya oleh manusia. Maka sebagai manusia mempunyai kewajiban untuk melestarikan dan membantu memperbaruinya, dengan cara memanfaatkan semaksimal mungkin.

Dipandang dari sudut hidrologis, situ mempunyai berbagai macam fungsi antara lain konservasi sumber daya air, yaitu mengurangi bahaya banjir dan kekeringan karena berfungsi sebagai retarding pada saat banjir sekaligus untuk pengisian kembali air tanah (recharge). Dipandang dari segi ekonomi, situ dapat menyediakan air baku baik secara langsung maupun tidak langsung, suplai untuk 
tanaman pangan, sebagai potensi daerah wisata dan juga untuk konservasi lingkungan sekitarnya. Untuk mendapatkan besarnya debit yang kita perlukan, sebelumnya harus mendapatkan data-data aliran sungai yang terdekat dan kemungkinannya sebagai sumber air untuk situ yang akan dibuat.

Saat ini untuk mendapatkan data-data tersebut tidaklah mudah, khususnya pada sungaisungai yang bukan merupakan sungai-sungai utama. Oleh karena itu cara lain yang dapat digunakan untuk mendapatkan data-data yang dibutuhkan adalah dengan menghitung dari data curah hujan yang terjadi pada daerah sekitar lokasi situ yang akan dibuat. Kemudian debit akan didapat dari hasil analisa hidrograf banjirnya. Dalam pembahasan nanti, akan dilakukan suatu analisa hidrologi yang menyangkut besarnya debit aliran ( inflow ) ke dalam situ baru, berdasarkan data yang ada. Sehingga sumber daya air yang ada, dapat dapat bermanfaat seoptimal mungkin dan diharapkan terjadi keseimbangan antara volume penyimpanan air dengan pengeluaran air.

Untuk memperoleh hasil yang sesuai dengan topik yang dibahas yaitu analisis kuantitas situ baru, maka perlu dilakukan pembatasan lingkup pembahasan. Pembatasan-pembatasan ini dilakukan berdasarkan ketersediaan data yang ada. Pembahasan mengenai hidrograf, pertama adalah tentang pengertian dari teori hidrograf, hidrograf satuan tentang pengenalan sistem dan linearitasnya, karakteristik hidrograf, hingga pada hidrograf satuan yang menunjukkan adanya hujan efektif yang kemudian ditransformasikan menjadi limpasan. Karena data-data mengenai observasi hidrograf banjir pada sungai-sungai yang tidak ada, maka penulis memakai hidrograf satuan sintesis untuk mencari Debit Banjir Rencana dan Debit Rata-rata Bulanan Andalan. Untuk mencari debit banjir digunakan metode Nakayasu dan untuk mendapatkan debit kering, maka digunakan metode NRECA. Tahap berikutnya adalah menarik kesimpulan yang diperoleh dari pengamatan dan analisa yang dilakukan.

\section{LOKASI STUDI DAN DATA}

\subsection{Lokasi Situ}

Lokasi rencana situ dengan luas area 1.5 ha terletak di kawasan kampus Universitas Indonesia (UI) Depok, Propinsi Jawa Barat terutama sekitar asrama mahasiswa Universitas Indonesia, di sebelah hilir jalan Lingkar Utara UI di sebelah hilir waduk UI lama (waduk UI-3) daerah tersebut berada di selatan DKI Jakarta. Lokasi dapat dicapai dari Jakarta dengan waktu sekitar 30-60 menit melalui jalan raya Jakarta - Depok - Bogor yang merupakan jalan propinsi tingkat I, maupun menggunakan kereta api trayek tetap Jakarta - Bogor yang melalui stasiun Kampus UI Depok. Wilayah selatan kampus UI Depok berbatasan dengan Kotip Depok, Jawa Barat, sedangkan bagian utara berbatasan dengan kecamatan Srengseng Pasar Minggu Jakarta.

Saat ini Universitas Indonesia memiliki jumlah mahasiswa kurang lebih 35.000 mahasiswa dan menempati lahan seluas 312 hektar. Dengan lahan seluas itu, hanya sepertiga luas lahan yang dipergunakan untuk mendirikan bangunan perkuliahan, sarana dan prasarana lainnya, sisanya berupa lahan konservasi yang terdiri dari hutan ( Tata Hijau ) dan situ-situ ( Ekosistem Perairan ). Sumber air untuk rencana Situ ini dari sungai yang telah dibendung di 6 lokasi dalam kampus UI membentuk waduk buatan yang diurutkan dari hulu adalah Situ Kenanga, Situ Aghatis, Situ Mahoni, Situ Puspa dan Situ Ulin ( yang tergabung menjadi satu, hanya dibatasi oleh jalan setapak), yang terakhir adalah Situ Salam. Yang aliran airnya saling berhubungan, kecuali Situ Kenanga. Situ-situ yang berada di wilayah kampus UI ini, mempunyai tiga inlet, yang masing-masing terdapat pada Situ Kenanga, Situ Aghatis dan Situ Mahoni. Air yang mengalir melalui inlet tersebut berasal dari saluran drainase penduduk sekitar dan aliran Sungai Kali Baru Barat yang merupakan anak Sungai Ciliwung. Dan outlet nya berada di Situ Salam, yang pada akhirnya bermuara di Sungai Kali Baru Barat juga.

Untuk mendapatkan gambaran mengenai rencana tata ruang wilayah kota Depok dan lokasi Situ baru dapat dilihat pada Gambar 1 dan Gambar 2.

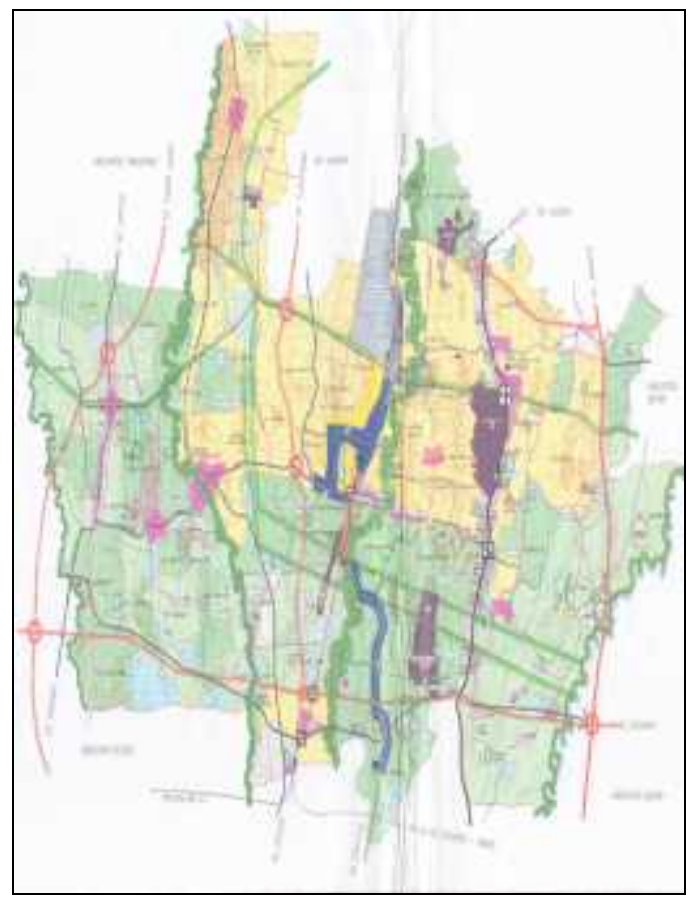

Gambar 1: Rencana Tata Ruang Wilayah Kota Depok Sumber : Pemda Depok 
Situ-situ tersebut dibuat mempunyai beberapa tujuan, diantaranya tujuan micro dan macro. Tujuan micro adalah untuk menjaga kelembapan suhu udara, konservasi air, dan penampungan drainase di sekitar kampus. Dan tujuan macro adalah sebagai tempat persapan air untuk wilayah Jakarta dan wilayah sekitar. Sehingga pada musim hujan, besaran laju limpasan dapat dikendalikan oleh situ-situ, hingga luapan air yang berlebihan dapat dicegah. Namun sebaliknya pada musim kemarau potensi air yang tersimpan pada situ tersebut dapat menjamin untuk dimanfaatkan oleh masyarakat kampus dan penduduk sekitar. Semakin lama, dengan jumlah penduduk sekitar kampus yang bertambah, jumlah mahasiswa yang semakin meningkat, suhu udara makin memanas akibat semakin menipisnya lapisan ozon dan sering terjadinya banjir di Jakarta, adanya lima situ yang berada di wilayah kampus UI dirasa kurang efektif lagi, maka perlu dibuat lagi sebuah situ baru untuk dapat memenuhi semua tujuan diatas. Situ baru yang akan dibuat, terletak disekitar Situ Puspa dengan asrama mahasiswa. Dengan desain luasan kurang lebih 1.5 ha dan dengan kedalaman $10 \mathrm{~m}$.

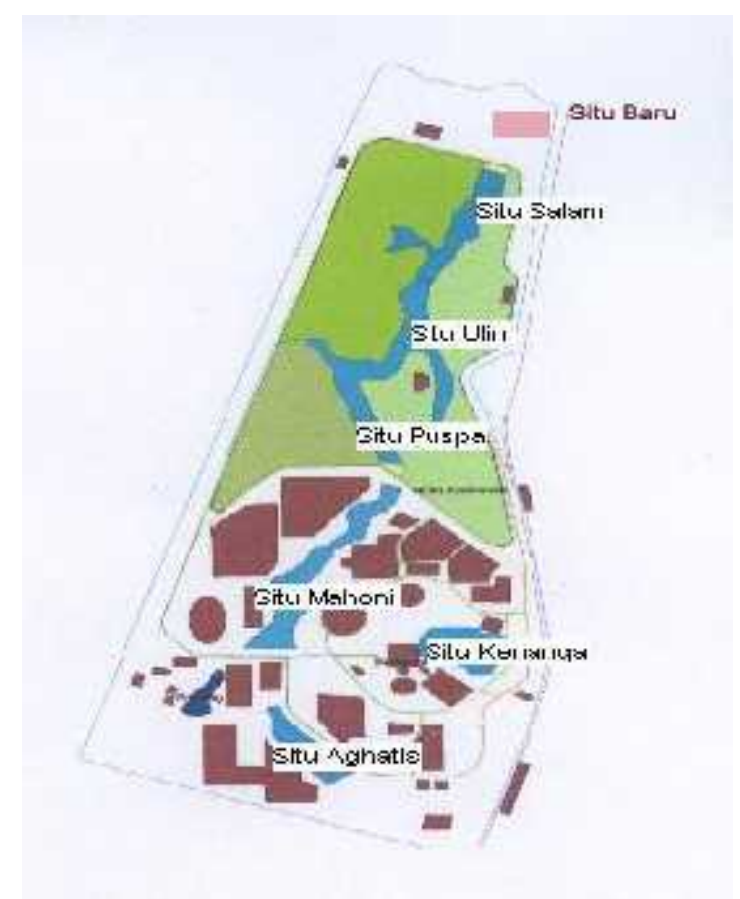

Gambar 2. Peta Universitas Indonesia Sumber : Gedung Biru, UI

\subsection{Curah Hujan dan Aliran Sungai}

Umumnya hujan turun sepanjang tahun dengan curah hujan maksimum $551 \mathrm{~mm} /$ bulan pada bulan Oktober sedangkan curah hujan minimum 3 $\mathrm{mm} /$ bulan pada bulan Agustus dan besarnya curah hujan rata-rata adalah $2556 \mathrm{~mm} /$ tahun. Secara regional kampus UI terletak pada daerah kipas aluvial dimana datarannya mempunyai kemiringan berkisar antara $10-15 \%$ hingga dibeberapa tempat didapat daerah bergelombang dan diarea depresi merupakan lembah aluvial sungai dengan lebar bervariasi antara $40 \mathrm{~m}$ sampai dengan $75 \mathrm{~m}$ dengan beda tinggi antara $2 \mathrm{~m}$ sampai dengan $5 \mathrm{~m}$. Daerah ini merupakan bagian dari daerah aliran Sungai Cisadane yang mengalir kearah utara yaitu kearah kota Jakarta. Dengan anak sungai Kali Baru Cabang Tengah. Aliran air yang akan masuk ke dalam Situ Baru ini adalah air yang mengalir dari sungai Kali Baru Cabang Tengah dan air yang berasal dari Situ yang ada sebelum Situ Pondok Cina, yaitu Situ Paladen. Data hujan bulanan maksimum dan data evapotranspirasi terlampir pada Tabel 1 dan Tabel 2 (Lampiran) .

\section{METODA DAN ANALISIS}

\subsection{Metoda Analisis}

Untuk mengukur debit rencana pada Situ Baru ini adalah harus menentukan debit kering dan debit banjirnya. Debit Rata-rata Bulanan dicari dengan menggunakan metode NRECA dan untuk menghitung debit banjirnya menggunakan hidrograf sintetik Nakayasu.

\subsubsection{Metode NRECA}

Untuk menghitung Debit Rata-rata Bulanan maka digunakan Metode Nreca. Debit aliran masuk kedalam situ berasal dari hujan yang turun di dalam cekungan (situ). Sebagian dari hujan tersebut akan menguap dan sebagian lagi turun mencapai permukaan tanah yang akan menjadi air limpasan dan air tanah itu sendiri. Yang akan mengisi pori-pori tanah. Jika pori-pori tanah sudah mengalami kejenuhan, air akan mengalir masuk kedalam tampungan air tanah. Gerak air ini disebut sebagai perkolasi. Sedikit demi sedikit air dari tampungan air tanah akan mengalir keluar sebagai mata air menuju alurnya dan disebut aliran dasar. Sisa curah hujan yang mengalir diatas permukaan, disebut aliran permukaan yang akan bersama aliran dasar akan menuju situ-situ.

Cara perhitungan ini paling sesuai untuk daerah yang mempunyai cekungan, yang setelah hujan berhenti masih ada aliran air di sungai selama beberapa hari. Kondisi ini akan terjadi bila tangkapan hujan cukup luas, sehingga cocok untuk dibuatnya situ yang ukurannya besar, walaupun metoda ini juga dapat digunakan untuk situ yang reletif kecil.

Berikut adalah hasil perhitungan debit kering menurut NRECA, Gambar 3 dan Gambar 4 memperlihatkan hubungan antara waktu dan Debit untuk thn 1985 - 2002. Debit andalan bulanan $Q_{80 \%}$ terlampir pada Tabel 3 (Lampiran). 


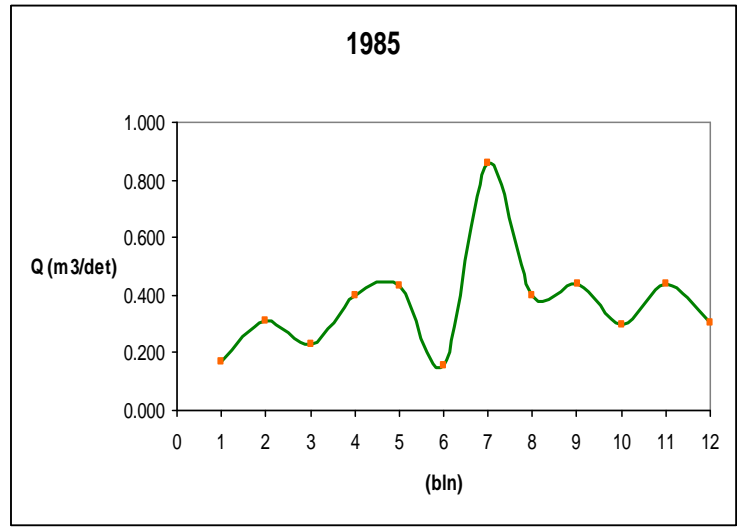

Gambar 3 : Debit Kering tahun 1985.

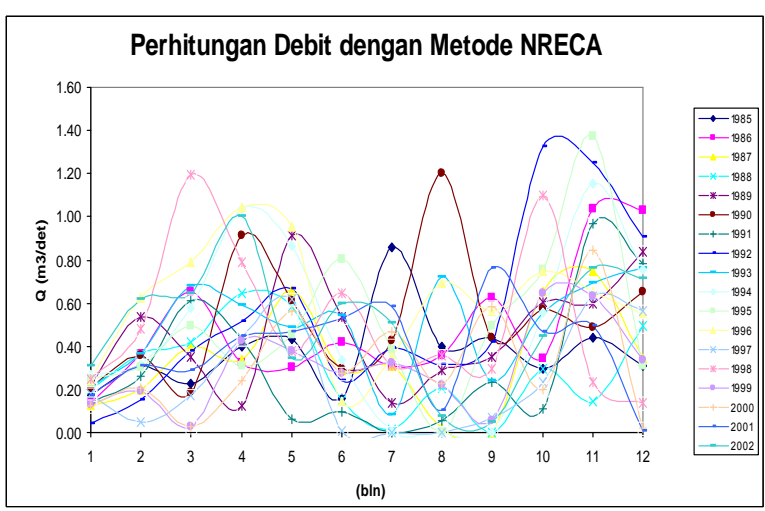

Gambar 4 : Debit Kering Tahun 1985-2002.

\subsubsection{Debit Banjir Rencana ( $\left.Q_{\text {banjir }}\right)$}

Untuk mengetahui Banjir Rencana harus ditentukan berdasarkan hujan, dengan sendirinya harus menetapkan besamya hujan rencana. Curah hujan rencana adalah hujan terbesar tahunan dengan sesuatu kemungkinan tertentu, atau hujan dengan suatu periode ulang tertentu.

Untuk rnenetapkan besarnya curah hujan rencana diadakan pengamatan hujan di daerah aliran sungai selama suatu periode cukup panjang. Salah satu cara yang dipermudah untuk menentukan besarnya hujan rencana adalah sebagai berikut :

1) Dengan pengamatan, meliputi besarnya hujan dalam satu hari, dua hari, tiga hari, empat hari, lima hari, tergantung pada tujuan penggunaannya.

2) Dari hasil pengamatan tersebut, ditentukan masa ulang untuk hujan masing-masing dengan analisa frekuensi.

3) Digambarkan pada grafik, disini akan didapat lengkung-lengkung yang menunjukan antara besar hujan selama suatu periode tertentu dan masa ulangnya.

Sebagai hujan rencana ditetapkan hujan dengan masa ulang tertentu. Dengan analisa frekuensi atau dengan hitung probabilitas dapat diramalkan seberapa besar harapan bahwa dalam suatu jangka waktu tertentu, misalnya 10 tahun, akan terjadi hujan-hujan yang besarnya sama dengan atau melebihi hujan rencana tadi. Juga dapat diramalkan seberapa besar harapan bahwa hujan rencana akan disamai atau dilampaui besamya.

Oleh karena tidak adanya pencatatan yang akurat pada daerah studi, maka yang dapat dipergunakan untuk melakukan analisis debit banjir rencana secara langsung dengan cara analisis frekuensi debit banjir maksimum tahunan, maka untuk analisis debit banjir rencana terlebih dahulu dilakukan analisis curah hujan.

\subsubsection{Analisis Frekuensi Hujan}

Analisis frekuensi data curah hujan rencana dapat dilakukan dengan menggunakan beberapa distribusi probabilitas dalam hidrologi, antara lain yaitu : Distribusi Gumbel dan Distribusi Log Pearson III. Pemilihan metode yang dapat digunakan di chek dari $X^{2}$ (Chi Kuadrat test), untuk mengetahui sejauh mana tingkat kecocokannya. Harga $X^{2}=0.05$ atau $5 \%$ merupakan batas dimana sebaran data percontohan populasi masih dapat dianggap cocok, bila $X^{2}<X_{0.05}$ maka data percontohan masih dapat dianggap mewakili populasi yang ada.

Tabel 4 : Hasil Perhitungan Curah Hujan Maksimum Rencana.

\begin{tabular}{|c|c|c|c|}
\hline No & Tr & $\begin{array}{c}\text { Gumbell } \\
(\mathrm{mm})\end{array}$ & $\begin{array}{c}\text { log Pearson III } \\
(\mathrm{mm})\end{array}$ \\
\hline 1 & 2 & 121.298 & 116.61 \\
\hline 2 & 5 & 166.887 & 152.62 \\
\hline 3 & 10 & 197.007 & 180.64 \\
\hline 4 & 50 & 263.497 & 254.83 \\
\hline 5 & 100 & 291.578 & 292.17 \\
\hline
\end{tabular}

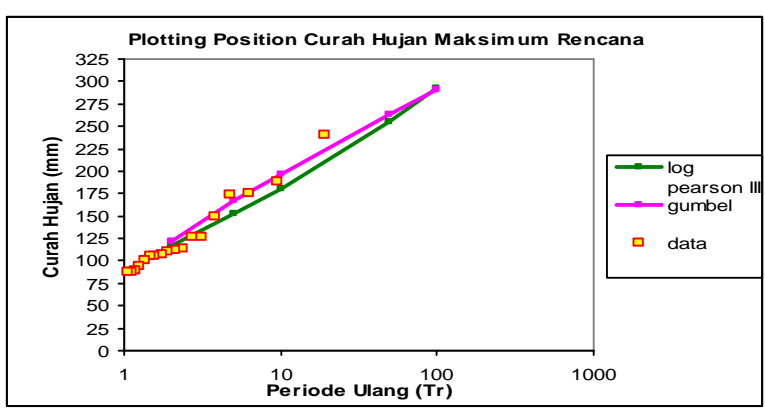

Gambar 5: Perhitungan Curah Hujan Maksimum Rencana.

Dari analisis frekuensi dengan metode Gumbel dan metode Log Pearson III, hasil pemeriksaan dengan 
metode Chi Kuadarat menyatakan bahwa kedua metode tersebut dapat digunakan. Karena $X^{2}$ sebaran Log Pearson III lebih kecil dari sebaran Gumbel, maka sebaran data percontoh lebih mengikuti sebaran kekerapan Log Pearson III. Dan jika dilihat dari grafik Plotting Possition Curah Hujan Harian Maksimum Rencana bahwa plotting yang ditunjukkan oleh data curah hujan yang ada, lebih mendekati pada grafik yang ditunjukkan oleh distribusi Log Pearson III. Sehingga distribusi yang dianggap paling memenuhi dan sesuai dengan data yang ada adalah distibusi Log Pearson III.

Tabel 5 : Distribusi Yang Sesuai.

\begin{tabular}{|c|c|c|}
\hline No & Tr & $\begin{array}{c}\text { Log Pearson III } \\
(\mathrm{mm})\end{array}$ \\
\hline 1 & 2 & 116.61 \\
\hline 2 & 5 & 152.62 \\
\hline 3 & 10 & 180.64 \\
\hline 4 & 50 & 254.83 \\
\hline 5 & 100 & 292.17 \\
\hline
\end{tabular}

\subsection{Distribusi Hujan Tiap Jam}

Oleh karena itu, karena tidak adanya data akibat pengukuran yang pasti maka digunakanlah pola pendekatan distribusi hujan untuk mendistribusikan hujan harian menjadi tiap jam. Data distribusi hujan jam-jaman ini diambil dari distribusi hujan yang ada pada Situ Empang, mengingat mempunyai induk aliran sungai yang sama yaitu melalui sungai Cisadane. Berikut adalah tabelnya:

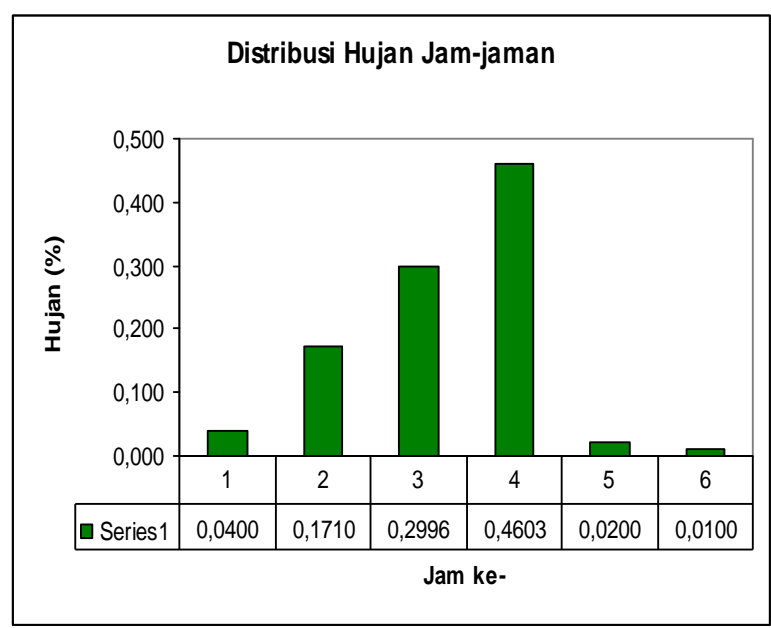

Sumber : Pengembangan SDA Cilcis PU

Gambar 6 : Distribusi Hujan Jam-Jaman.

\subsection{Metode NAKAYASU}

Dikarenakan adanya keterbatasan yang ada maka digunakan metode hidrograf sintetik untuk mendapatkan debit Banjir Rencana dengan kala ulang tertentu. Dari metode ini akan didapatkan nilainilai puncak debit banjir (Qp;mm3/det). Metode ini juga biasanya digunakan untuk situ yang luasannya tidak terlalu besar tetapi berada di luasan daerah pengaliran yang sangat luas. Dan menghasilkan rumus sebagai berikut :

$$
C_{p}=\frac{C \times A \times R_{0}}{3.6\left(0.3 T_{p}+T_{0.3}\right)}
$$

Qp : Debit puncak banjir(m3/det)

RO : Hujan satuan ( $\mathrm{mm}$ )

Tp : Tenggang waktu dari permulaan hujan sampai puncak banjir (jam)

T0.3 : Waktu yang diperlukan oleh penurunan debit, dari debit puncak sampai menjadi $30 \%$ dari debit puncak (jam)

$$
Q_{n}=Q_{p}\left(\frac{t}{T_{p}}\right)^{2.4}
$$

Qn : Limpasan sebelum mencapai debit puncak (m3/det)

$\mathrm{T} \quad$ : wWktu (jam) bagian lengkung turun (aecreasing limb):

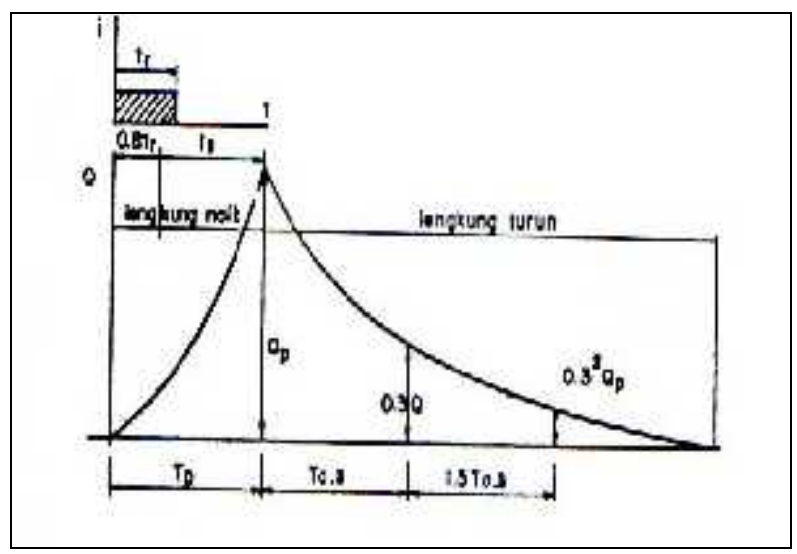

Sumber : Hidrologi Teknik

Gambar 7: Hirdrograf Sintetik NAKAYASU.

Hasil perhitungan banjir rencana dengan Metoda Nakayasu dapat dilihat pada lampiran Tabel 4. dan Tabel 5. Untuk lebih jelasnya hasil perhitungan di tampilkan dalam bentuk kurva pada Gambar 8 dan Gambar 9 . 


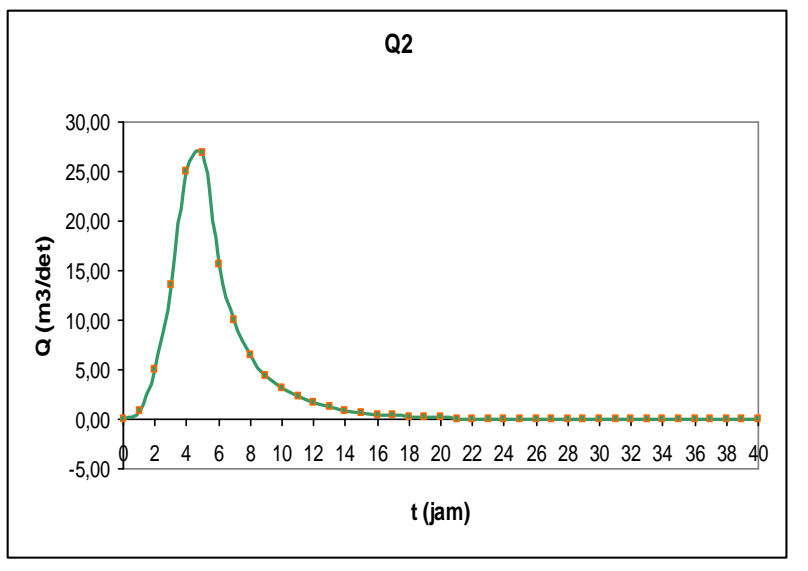

Gambar 8: Hidrograf Debit Banjir Rencana $\left(Q_{2}\right)$.

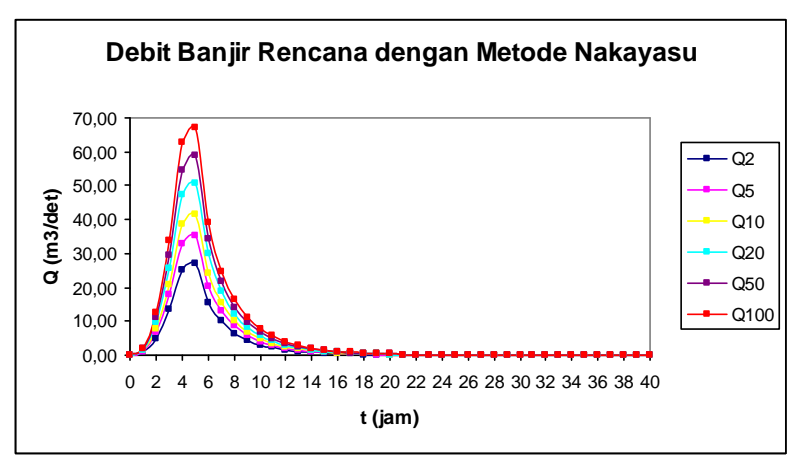

Gambar 9 : Hidrograf Debit Banjir Rencana.

\section{Kesimpulan dan Saran}

\subsection{Kesimpulan}

- Dari perhitungan yang telah dilakukan pada Situ Baru didapat bahwa Debit Andalan semakin meningkat dengan debit rata-rata 0,382 $\mathrm{m3} /$ det sehingga dapat menjadi sumber cadangan air. Debit Banjir telah dapat diperkirakan dengan perioda ulang 50 tahun $60,722 \mathrm{~m} 3 /$ det. Hal ini menunjukkan bahwa dengan adanya Situ Baru maka akan memberikan manfaat bagi tata air dan masyarakat sekitarnya.

- Pola distribusi hujan yang ada pada Situ Empang, dapat digunakan untuk analisa debit, mengingat mempunyai induk aliran sungai yang sama yaitu melalui sungai Cisadane.

- Metode Nreca dapat digunakan untuk menghitung Debit Rata-rata Bulanan dan Metode Hidrograf Sintetik Nakayasu untuk menghitung Debit Banjirnya.

\subsection{Saran}

- Untuk mengoptimalkan Situ Baru ini, dapat dilakukan dengan memperluas ataupun memperdalam dimensi Situ.
- Diperlukan adanya stasiun-stasiun pencatat hujan agar mendapatkan hasil pengukuran yang lebih baik.

- Adanya hasil pengamatan tentang Evaporasi yang akurat, sehingga dapat menghasilkan perhitungan yang baik.

- Diperlukan hasil pencatatan hujan yang lebih akurat.

- Perlu diadakannya penelitian tentang Pola Distribusi Hujan pada daerah Bogor dan sekitarnya.

- Untuk hasil yang lebih akurat tentang Debit, maka ada baiknya dilakukan suatu perhitungan dengan menggunakan Metode-metode lainnya, sehingga dapat dilakukan perbandingan.

\section{DAFTAR PUSTAKA}

- Harto, Sri. 1993. Analisis Hidrologi. Jakarta. PT Gramedia Pustaka Utama.

- Kasiro, Ibnu, Wanny Adhidarma, BS Rusli, CL Nugroho, Sunarto. 1994. Pedoman Kriteria Desain Embung Kecil Untuk Daerah Semi Kering Di Indonesia. Jakarta. Departemen Pekerjaan Umum.

- Kinsley, Ray K. 1989. Hidrologi Untuk Insinyur. Jakarta. Erlangga.

- Kinsley, Ray K. 1991. Teknik Sumber Daya Air. Jakarta. Erlangga.

- Singh, E Vijay P. 1975. Elementary Hydrology. Department of Civil Engineering Lousiana State University.

- Soemartono, CD. 1995. Hidrologi Teknik. Jakarta. Erlangga.

- W.J, Martha, Adhidarma W. 1982. Mengenal Dasar-dasar Hidrologi. Jakarta. Nova. 
Lampiran :

Tabel 1 : Data Hujan Harian Maksimum Dan Atau Data Hujan Bulanan Maksimum.

\begin{tabular}{|c|c|c|c|c|c|c|c|c|c|c|c|c|}
\hline \multicolumn{10}{|c|}{ Curah Hujan (mm) } \\
\hline Tahun & jan & feb & mar & ap & mei & jun & jul & agust & sept & okt & nov & dec \\
\hline 1985 & 375 & 353 & 231 & 337 & 323 & 156 & 514 & 285 & 298 & 232 & 279 & 213 \\
\hline 1986 & 311 & 436 & 526 & 233 & 241 & 281 & 232 & 264 & 387 & 252 & 543 & 528 \\
\hline 1987 & 295 & 282 & 404 & 293 & 460 & 218 & 235 & 103 & 50 & 413 & 436 & 213 \\
\hline 1988 & 434 & 381 & 344 & 445 & 371 & 148 & 89 & 200 & 80 & 243 & 151 & 307,2 \\
\hline 1989 & 464,1 & 505,9 & 280,9 & 150,2 & 553,6 & 333 & 147,3 & 230,2 & 255,1 & 367,2 & 345,9 & 443,6 \\
\hline 1990 & 442,4 & 373,4 & 192,8 & 638,6 & 381,8 & 211,9 & 283 & 645,5 & 288,1 & 346,3 & 291,8 & 357,8 \\
\hline 1991 & 311,5 & 348,3 & 547,1 & 306,2 & 117,2 & 125,1 & 7,3 & 121,8 & 214,9 & 154 & 559,5 & 439,3 \\
\hline 1992 & 132 & 301,4 & 444,8 & 426,8 & 441,5 & 193 & 276,7 & 244,7 & 288,3 & 705,1 & 638 & 470,7 \\
\hline 1993 & 461,9 & 365,8 & 518,7 & 382,5 & 323,4 & 329,7 & 121 & 427,4 & 202,3 & 345,5 & 389,5 & 409,5 \\
\hline 1994 & 562,7 & 322,59 & 445,7 & 593,3 & 489,6 & 229,1 & 30,4 & 45,4 & 45,4 & 363,5 & 609,9 & 413,8 \\
\hline 1995 & 516,3 & 312,7 & 383,5 & 245,3 & 318 & 470,4 & 263,5 & 9,8 & 335,3 & 455,8 & 708,9 & 212,7 \\
\hline 1996 & 508,3 & 537,4 & 504,3 & 596,4 & 517,7 & 138,4 & 243,4 & 403 & 342,4 & 424,7 & 354,8 & 307,8 \\
\hline 1997 & 390,8 & 109,3 & 230,4 & 404,4 & 457,3 & 50,6 & 24,2 & 33,8 & 136,4 & 231 & 421,5 & 357,4 \\
\hline 1998 & 523,6 & 423,4 & 773,3 & 455,7 & 259,3 & 369,3 & 221,8 & 252,3 & 224,9 & 573,1 & 180,6 & 135,2 \\
\hline 1999 & 306,2 & 270,8 & 97,6 & 398 & 325,5 & 228,6 & 257,3 & 207,4 & 122,9 & 421 & 381,3 & 234,1 \\
\hline $\mathbf{2 0 0 0}$ & 297,3 & 285,9 & 98,4 & 276,2 & 461,4 & 227,1 & 326,7 & 208,5 & 377,6 & 191 & 479,9 & 78,8 \\
\hline $\mathbf{2 0 0 1}$ & 382,8 & 352,1 & 276,3 & 363,9 & 334,5 & 340,4 & 365,8 & 142,3 & 444,7 & 307,2 & 304,1 & 69,6 \\
\hline $\mathbf{2 0 0 2}$ & 628,9 & 475,3 & 414,2 & 576,7 & 240,2 & 345,4 & 312,5 & 128,2 & 118,4 & 297,7 & 415,7 & 384,9 \\
\hline
\end{tabular}

Sumber : BMG, Jakarta

Tabel 2 : Data Evapotranspirasi (Penguapeluhan) Dan Evaporasi (Penguapan) Bulanan.

\begin{tabular}{|c|c|c|c|c|c|c|c|c|}
\hline \multirow[b]{2}{*}{ No } & \multirow[b]{2}{*}{ Bulan } & \multicolumn{2}{|c|}{ Temperatur $\left({ }^{\circ} \mathrm{C}\right)$} & \multirow{2}{*}{$\begin{array}{c}\text { Kelembapan } \\
\text { Udara } \\
(\%)\end{array}$} & \multirow{2}{*}{$\begin{array}{c}\begin{array}{c}\text { Kecepatan } \\
\text { Angin }\end{array} \\
(\mathrm{km} / \text { hari }) \\
\end{array}$} & \multirow{2}{*}{$\begin{array}{c}\text { Penyinaran } \\
\text { Matahari } \\
\text { (jam) }\end{array}$} & \multirow{2}{*}{$\begin{array}{l}\text { Solar rad. } \\
\mathrm{MJ} / \mathrm{m} 2 / \mathrm{hr}\end{array}$} & \multirow{2}{*}{$\begin{array}{c}\text { Eto } \\
\text { (evapotranspirasi) } \\
(\mathrm{mm} / \mathrm{bln})\end{array}$} \\
\hline & & max. & $\min$. & & & & & \\
\hline 1 & jan & 24,40 & 24,40 & 90,00 & 44,10 & 2,70 & 13,80 & 87,73 \\
\hline 2 & feb & 24,60 & 24,60 & 88,80 & 44,10 & 3,50 & 15,30 & 86,52 \\
\hline 3 & mar & 24,80 & 24,80 & 88,90 & 75,20 & 4,00 & 15,80 & 98,58 \\
\hline 4 & ap & 25,40 & 25,40 & 87,20 & 44,90 & 6,30 & 18,30 & 107,40 \\
\hline 5 & mei & 25,40 & 25,40 & 87,10 & 44,90 & 7,80 & 18,90 & 110,67 \\
\hline 6 & jun & 25,10 & 25,10 & 84,70 & 44,90 & 7,40 & 17,40 & 97,50 \\
\hline 7 & jul & 25,10 & 25,10 & 82,40 & 44,90 & 8,30 & 19,00 & 108,81 \\
\hline 8 & agust & 25,50 & 25,50 & 82,60 & 44,90 & 8,50 & 20,70 & 122,14 \\
\hline 9 & sept & 25,30 & 25,30 & 81,70 & 57,90 & 7,50 & 20,70 & 121,20 \\
\hline 10 & okt & 25,50 & 25,50 & 83,00 & 44,90 & 6,70 & 20,10 & 123,69 \\
\hline 11 & nov & 25,30 & 25,30 & 85,20 & 57,90 & 4,90 & 17,20 & 105,00 \\
\hline 12 & dec & 24,90 & 24,90 & 87,50 & 75,20 & 4,90 & 15,70 & 99,20 \\
\hline
\end{tabular}

Sumber : Pekerjaan Desain Situ dan Waduk Resapan, Kabupaten Bogor-Depok, PU 
Tabel 3 : Debit Andalan Bulanan (Q80\%).

\begin{tabular}{|c|c|c|c|c|c|c|c|c|c|c|c|}
\hline jan & feb & mar & ap & mei & jun & jul & agust & sept & okt & nov & dec \\
\hline 0.0378 & 0.0453 & 0.0259 & 0.1250 & 0.0635 & 0.0060 & 0.0006 & 0.0001 & 0.0000 & 0.1128 & 0.1456 & 0.0050 \\
\hline 0.1257 & 0.1488 & 0.0269 & 0.2384 & 0.3026 & 0.0980 & 0.0010 & 0.0004 & 0.0005 & 0.1996 & 0.2353 & 0.0173 \\
\hline 0.1270 & 0.1944 & 0.1715 & 0.3057 & 0.3407 & 0.1444 & 0.0039 & 0.0042 & 0.0019 & 0.2305 & 0.4382 & 0.1345 \\
\hline 0.1318 & 0.1998 & 0.1823 & 0.3200 & 0.3758 & 0.1518 & 0.0165 & 0.0225 & 0.0495 & 0.2934 & 0.4846 & 0.3057 \\
\hline 0.1344 & 0.2035 & 0.2268 & 0.3339 & 0.3809 & 0.1573 & 0.0795 & 0.0581 & 0.0545 & 0.2980 & 0.4960 & 0.3107 \\
\hline 0.1346 & 0.2617 & 0.2886 & 0.3964 & 0.4350 & 0.2405 & 0.1342 & 0.0736 & 0.0667 & 0.3437 & 0.5966 & 0.3364 \\
\hline 0.1689 & 0.3012 & 0.3519 & 0.4289 & 0.4533 & 0.2734 & 0.3062 & 0.1020 & 0.2319 & 0.4489 & 0.6311 & 0.3457 \\
\hline 0.1731 & 0.3072 & 0.3783 & 0.4325 & 0.4687 & 0.2758 & 0.3070 & 0.2085 & 0.2391 & 0.4666 & 0.6329 & 0.4932 \\
\hline 0.1774 & 0.3081 & 0.4006 & 0.4389 & 0.4897 & 0.2878 & 0.3079 & 0.2210 & 0.2953 & 0.5529 & 0.6514 & 0.5499 \\
\hline 0.2007 & 0.3135 & 0.4196 & 0.4460 & 0.5599 & 0.2920 & 0.3201 & 0.2246 & 0.3518 & 0.5579 & 0.6945 & 0.5650 \\
\hline 0.2053 & 0.3603 & 0.4960 & 0.5134 & 0.5811 & 0.3385 & 0.3511 & 0.2876 & 0.4161 & 0.5691 & 0.7483 & 0.6535 \\
\hline 0.2158 & 0.3614 & 0.5788 & 0.5883 & 0.6125 & 0.4162 & 0.3841 & 0.3138 & 0.4382 & 0.6020 & 0.7606 & 0.7115 \\
\hline 0.2170 & 0.3616 & 0.6097 & 0.6469 & 0.6190 & 0.5258 & 0.3934 & 0.3538 & 0.4425 & 0.6482 & 0.8469 & 0.7572 \\
\hline 0.2408 & 0.3660 & 0.6473 & 0.7911 & 0.6592 & 0.5337 & 0.4261 & 0.3559 & 0.4913 & 0.6546 & 0.9690 & 0.7597 \\
\hline 0.2451 & 0.4803 & 0.6503 & 0.9100 & 0.6628 & 0.5419 & 0.4672 & 0.3983 & 0.5663 & 0.7486 & 1.0391 & 0.7856 \\
\hline 0.2491 & 0.5378 & 0.6830 & 1.0053 & 0.8655 & 0.5941 & 0.5088 & 0.6921 & 0.5805 & 0.7570 & 1.1528 & 0.8366 \\
\hline 0.2702 & 0.6206 & 0.7883 & 1.0382 & 0.9138 & 0.6471 & 0.5862 & 0.7207 & 0.6222 & 1.0959 & 1.2486 & 0.9049 \\
\hline 0.3059 & 0.6225 & 1.1966 & 1.0466 & 0.9573 & 0.8030 & 0.8603 & 1.1996 & 0.7603 & 1.3269 & 1.3710 & 1.0329 \\
\hline
\end{tabular}


Tabel 4 : Perhitungan Debit Banjir Dengan Metode Nakayasu.

METODE HIDROGRAF NAKAYASU

\begin{tabular}{|c|c|c|c|c|c|c|c|c|c|}
\hline \multirow{3}{*}{$\begin{array}{l}\text { hujan Rencana R2 } \\
\text { distribusi Rrencana }\end{array}$} & $=$ & 116,61 & $\mathrm{~mm}$ & & & & & & \\
\hline & \multirow{2}{*}{$=$} & $\mathrm{t}$ & 1 & 2 & 3 & 4 & 5 & 6 & jam \\
\hline & & hujan & 0,0400 & 0,1701 & 0,2996 & 0,4603 & 0,0200 & 0,0100 & $\mathrm{~mm} / \mathrm{jam}$ \\
\hline \multirow[t]{2}{*}{ hujan efektif } & \multirow[t]{2}{*}{$=$} & $\mathrm{t}$ & 1 & 2 & 3 & 4 & 5 & 6 & jam \\
\hline & & hujan & 4,6644 & 19,8354 & 34,9364 & 53,6756 & 2,3322 & 1,1661 & $\mathrm{~mm} / \mathrm{jam}$ \\
\hline
\end{tabular}

\begin{tabular}{|c|c|c|c|c|c|c|c|c|c|}
\hline \multicolumn{10}{|c|}{ Akibat Hujan (mm) } \\
\hline$t$ & $U(t, 1)$ & 4,664 & 19,835 & 34,936 & 53,676 & 2,332 & 1,166 & total & ket \\
\hline 0 & 0,000 & 0,000 & & & & & & 0,000 & $\mathrm{Qa}$ \\
\hline 1 & 0,174 & 0,811 & 0,000 & & & & & 0,811 & Qa \\
\hline 2 & 0,334 & 1,557 & 3,448 & 0,000 & & & & 5,005 & Qd1 \\
\hline 3 & 0,176 & 0,819 & 6,620 & 6,073 & 0,000 & & & 13,512 & Qd1 \\
\hline 4 & 0,106 & 0,493 & 3,484 & 11,659 & 9,331 & 0,000 & & 24,967 & Qd2 \\
\hline 5 & 0,069 & 0,321 & 2,096 & 6,137 & 17,913 & 0,405 & 0,000 & 26,872 & Qd2 \\
\hline 6 & 0,045 & 0,209 & 1,366 & 3,691 & 9,429 & 0,778 & 0,203 & 15,676 & Qd2 \\
\hline 7 & 0,032 & 0,149 & 0,891 & 2,406 & 5,671 & 0,410 & 0,389 & 9,915 & Qd2 \\
\hline 8 & 0,023 & 0,108 & 0,633 & 1,569 & 3,697 & 0,246 & 0,205 & 6,458 & Qd3 \\
\hline 9 & 0,017 & 0,078 & 0,459 & 1,115 & 2,410 & 0,161 & 0,123 & 4,347 & Qd3 \\
\hline 10 & 0,012 & 0,057 & 0,333 & 0,809 & 1,714 & 0,105 & 0,080 & 3,098 & Qd3 \\
\hline 11 & 0,009 & 0,041 & 0,242 & 0,587 & 1,243 & 0,074 & 0,052 & 2,240 & Qd3 \\
\hline 12 & 0,006 & 0,030 & 0,175 & 0,426 & 0,902 & 0,054 & 0,037 & 1,624 & Qd3 \\
\hline 13 & 0,005 & 0,022 & 0,127 & 0,309 & 0,654 & 0,039 & 0,027 & 1,179 & Qd3 \\
\hline 14 & 0,003 & 0,016 & 0,092 & 0,224 & 0,475 & 0,028 & 0,020 & 0,855 & Qd3 \\
\hline 15 & 0,002 & 0,011 & 0,067 & 0,163 & 0,344 & 0,021 & 0,014 & 0,620 & Qd3 \\
\hline 16 & 0,002 & 0,008 & 0,049 & 0,118 & 0,250 & 0,015 & 0,010 & 0,450 & Qd3 \\
\hline 17 & 0,001 & 0,006 & 0,035 & 0,086 & 0,181 & 0,011 & 0,007 & 0,327 & Qd3 \\
\hline 18 & 0,001 & 0,004 & 0,026 & 0,062 & 0,132 & 0,008 & 0,005 & 0,237 & Qd3 \\
\hline 19 & 0,001 & 0,003 & 0,019 & 0,045 & 0,095 & 0,006 & 0,004 & 0,172 & Qd3 \\
\hline 20 & 0,000 & 0,002 & 0,013 & 0,033 & 0,069 & 0,004 & 0,003 & 0,125 & Qd3 \\
\hline 21 & 0,000 & 0,002 & 0,010 & 0,024 & 0,050 & 0,003 & 0,002 & 0,090 & Qd3 \\
\hline 22 & 0,000 & 0,001 & 0,007 & 0,017 & 0,036 & 0,002 & 0,002 & 0,066 & Qd3 \\
\hline 23 & 0,000 & 0,001 & 0,005 & 0,012 & 0,026 & 0,002 & 0,001 & 0,048 & Qd3 \\
\hline 24 & 0,000 & 0,001 & 0,004 & 0,009 & 0,019 & 0,001 & 0,001 & 0,035 & Qd3 \\
\hline 25 & 0,000 & 0,000 & 0,003 & 0,007 & 0,014 & 0,001 & 0,001 & 0,025 & Qd3 \\
\hline 26 & 0,000 & 0,000 & 0,002 & 0,005 & 0,010 & 0,001 & 0,000 & 0,018 & Qd3 \\
\hline 27 & 0,000 & 0,000 & 0,001 & 0,003 & 0,007 & 0,000 & 0,000 & 0,013 & Qd3 \\
\hline 28 & 0,000 & 0,000 & 0,001 & 0,003 & 0,005 & 0,000 & 0,000 & 0,010 & Qd3 \\
\hline 29 & 0,000 & 0,000 & 0,001 & 0,002 & 0,004 & 0,000 & 0,000 & 0,007 & Qd3 \\
\hline 30 & 0,000 & 0,000 & 0,001 & 0,001 & 0,003 & 0,000 & 0,000 & 0,005 & Qd3 \\
\hline 31 & 0,000 & 0,000 & 0,000 & 0,001 & 0,002 & 0,000 & 0,000 & 0,003 & Qd3 \\
\hline 32 & 0,000 & 0,000 & 0,000 & 0,001 & 0,001 & 0,000 & 0,000 & 0,002 & Qd3 \\
\hline 33 & 0,000 & 0,000 & 0,000 & 0,001 & 0,001 & 0,000 & 0,000 & 0,002 & Qd3 \\
\hline 34 & 0,000 & 0,000 & 0,000 & 0,000 & 0,001 & 0,000 & 0,000 & 0,001 & Qd3 \\
\hline 35 & 0,000 & 0,000 & 0,000 & 0,000 & 0,001 & 0,000 & 0,000 & 0,001 & Qd3 \\
\hline 36 & 0,000 & 0,000 & 0,000 & 0,000 & 0,000 & 0,000 & 0,000 & 0,000 & Qd3 \\
\hline 37 & 0,000 & 0,000 & 0,000 & 0,000 & 0,000 & 0,000 & 0,000 & 0,000 & Qd3 \\
\hline 38 & 0,000 & 0,000 & 0,000 & 0,000 & 0,000 & 0,000 & 0,000 & 0,000 & Qd3 \\
\hline 39 & 0,000 & 0,000 & 0,000 & 0,000 & 0,000 & 0,000 & 0,000 & 0,000 & Qd3 \\
\hline 40 & 0,000 & 0,000 & 0,000 & 0,000 & 0,000 & 0,000 & 0,000 & 0,000 & Qd3 \\
\hline
\end{tabular}


Tabel 5 : Debit Banjir Dengan Metode Nakayasu.

Berikut adalah hasil Debit Banjir Rencana dari $R_{2}, R_{5}, R_{10}, R_{25}, R_{50}, R_{100}$ :

\begin{tabular}{|c|c|c|c|c|c|c|}
\hline \multicolumn{7}{|c|}{ Debit Banjir Rencana ( $\left.\mathrm{m}^{3} / \mathrm{det}\right)$} \\
\hline $\mathbf{t}$ & $\mathbf{Q}_{2}$ & $Q_{5}$ & $\mathbf{Q}_{10}$ & $\mathbf{Q}_{25}$ & $Q_{50}$ & $Q_{100}$ \\
\hline 0 & 0,000 & 0,000 & 0,000 & 0,000 & 0,000 & 0,000 \\
\hline 1 & 0,811 & 1,061 & 1,256 & 1,536 & 1,772 & 2,032 \\
\hline 2 & 5,005 & 6,550 & 7,753 & 9,483 & 10,937 & 12,540 \\
\hline 3 & 13,512 & 17,685 & 20,932 & 25,604 & 29,529 & 33,855 \\
\hline 4 & 24,967 & 32,677 & 38,677 & 47,309 & 54,561 & 62,556 \\
\hline 5 & 26,872 & 35,171 & 41,628 & 50,920 & 58,725 & 67,330 \\
\hline 6 & 15,676 & 20,517 & 24,284 & 29,704 & 34,258 & 39,277 \\
\hline 7 & 9,915 & 12,977 & 15,359 & 18,788 & 21,668 & 24,843 \\
\hline 8 & 6,458 & 8,452 & 10,004 & 12,237 & 14,112 & 16,180 \\
\hline 9 & 4,347 & 5,689 & 6,734 & 8,237 & 9,499 & 10,891 \\
\hline 10 & 3,098 & 4,055 & 4,799 & 5,870 & 6,770 & 7,762 \\
\hline 11 & 2,240 & 2,932 & 3,470 & 4,245 & 4,895 & 5,613 \\
\hline 12 & 1,624 & 2,126 & 2,516 & 3,078 & 3,550 & 4,070 \\
\hline 13 & 1,179 & 1,542 & 1,826 & 2,233 & 2,576 & 2,953 \\
\hline 14 & 0,855 & 1,119 & 1,325 & 1,620 & 1,869 & 2,142 \\
\hline 15 & 0,620 & 0,812 & 0,961 & 1,175 & 1,356 & 1,554 \\
\hline 16 & 0,450 & 0,589 & 0,697 & 0,853 & 0,984 & 1,128 \\
\hline 17 & 0,327 & 0,427 & 0,506 & 0,619 & 0,714 & 0,818 \\
\hline 18 & 0,237 & 0,310 & 0,367 & 0,449 & 0,518 & 0,594 \\
\hline 19 & 0,172 & 0,225 & 0,266 & 0,326 & 0,376 & 0,431 \\
\hline 20 & 0,125 & 0,163 & 0,193 & 0,236 & 0,272 & 0,312 \\
\hline 21 & 0,090 & 0,118 & 0,140 & 0,171 & 0,198 & 0,227 \\
\hline 22 & 0,066 & 0,086 & 0,102 & 0,124 & 0,143 & 0,164 \\
\hline 23 & 0,048 & 0,062 & 0,074 & 0,090 & 0,104 & 0,119 \\
\hline 24 & 0,035 & 0,045 & 0,054 & 0,065 & 0,075 & 0,087 \\
\hline 25 & 0,025 & 0,033 & 0,039 & 0,047 & 0,055 & 0,063 \\
\hline 26 & 0,018 & 0,024 & 0,028 & 0,034 & 0,040 & 0,046 \\
\hline 27 & 0,013 & 0,017 & 0,020 & 0,025 & 0,029 & 0,033 \\
\hline 28 & 0,010 & 0,013 & 0,015 & 0,018 & 0,021 & 0,024 \\
\hline 29 & 0,007 & 0,009 & 0,011 & 0,013 & 0,015 & 0,017 \\
\hline 30 & 0,005 & 0,007 & 0,008 & 0,010 & 0,011 & 0,013 \\
\hline 31 & 0,003 & 0,005 & 0,006 & 0,007 & 0,008 & 0,009 \\
\hline 32 & 0,002 & 0,003 & 0,004 & 0,005 & 0,006 & 0,007 \\
\hline 33 & 0,002 & 0,002 & 0,003 & 0,003 & 0,003 & 0,005 \\
\hline 34 & 0,001 & 0,001 & 0,002 & 0,002 & 0,003 & 0,003 \\
\hline 35 & 0,001 & 0,001 & 0,001 & 0,002 & 0,002 & 0,002 \\
\hline 36 & 0,000 & 0,001 & 0,001 & 0,001 & 0,001 & 0,001 \\
\hline 37 & 0,000 & 0,000 & 0,000 & 0,001 & 0,001 & 0,001 \\
\hline 38 & 0,000 & 0,000 & 0,000 & 0,000 & 0,000 & 0,001 \\
\hline 39 & 0,000 & 0,000 & 0,000 & 0,000 & 0,000 & 0,000 \\
\hline 40 & 0,000 & 0,000 & 0,000 & 0,000 & 0,000 & 0,000 \\
\hline
\end{tabular}

